JERZY GROBIS

UNIWERSYTET ŁÓDZKI

\title{
Dyskurs o dyskursie - oświecenie w wybranych tekstach postmodernizmu
}

Postmodernizm upatruje źródeł większości chorób współczesnej cywilizacji w bezkrytycznym uwielbieniu oświeconych dla ludzkiego rozumu zdolnego zapanować nad przyroda dla dobra ludzkości. Sceptycznie ocenia wiarę wieku świateł w uwolnienie człowieka od niedostatków materialnych i poszerzenie jego praw obywatelskich w państwie. $Z$ dzisiejszej, czyli ponowoczesnej, perspektywy, wzniosłe propozycje oświeconych wydają się iluzoryczne i rzadko bywaja potwierdzone w praktyce życia społecznego. Nadal ludzkość boryka się $z$ problemem nierówności materialnej i niesprawiedliwości społecznej, co wedle projektów osiemnastowiecznych byłoby możliwe do przezwyciężenia dzięki powszechnej oświacie i postępowi naukowo-technicznemu1. W rzeczywistości, rywalizacja państw narodowych ostatnich stuleci ułatwiła przekształcanie ich w systemy totalitarne o konfrontacyjnym nastawieniu. Towarzyszace temu zbrojenia, lansowane przez rządzacych pod szyldem projektów modernizacji państwa, i w ich następstwie prowadzone wojny wydatnie opóźniały postęp materialny i poważnie ograniczyły polityczne wolności społeczeństw² ${ }^{2}$ Nic też dziwnego, że czołowi przed-

${ }^{1}$ Można odwołać się tutaj do standardowych pozycji europejskiego oświecenia: W o 1 t e r, Elementy filozofii Newtona, Warszawa 2010 i A.N. C o n d o r c et, Szkice obrazu postępu ducha ludzkiego poprzez dzieje, Warszawa 1957. W postmodernizmie istotny jest nurt krytycznej oceny wszelkich ujęć odwołujących się do działań celowych, a takie zabarwienie maja klasyczne publikacje osiemnastowieczne. Więcej na ten temat por. M. Horkh e i m e r, Th.W. A d o r n o, Dialektyka oświecenia, Warszawa 2010.

2 Warto przypomnieć jedno $z$ fundamentalnych stwierdzeń J. Habermasa, że właściwą funkcja języka jest stworzenie miejsca dla komunikacji i tam gdzie to nie zachodzi lub się nie udaje, występuje patologiczna forma posługiwania się 
stawiciele postmodernizmu wskazuja na państwo, a nie społeczeństwo, jako ostatecznego zwycięzcę. To ono, przybierając formę monolitycznego, scentralizowanego aparatu władzy skutecznie ograniczyło prawa obywatelskie jednostek. Doszło do tego w państwach faszystowskich, które w imię wspólnoty krwi i ziemi stały się państwami stanu wyjatkowego, podobnie jak państwa komunistyczne, szermujące hasłem walki klas. Stąd myśl postmodernistyczna zakwestionowała dorobek ideowy wieku swiateł wyartykułowany w rewolucyjnym sloganie o wolności, równości i sprawiedliwości wszystkich ludzi. Innymi słowy, wielkie patetyczne narracje, jakie ożywiały wyobraźnię społeczna nowożytności, utraciły współcześnie swoja moc, okazując się jedynie socjotechnicznym zabiegiem, o propagandowym wymiarze, umiejętnie wykorzystanym przez władzę ${ }^{3}$.

Jednym $z$ podstawowych narzędzi, dzięki któremu nastapił rzeczywisty sojusz władzy i wiedzy, okazała się umiejętność skutecznego operowania słowem przez elitę władzy, tak by przekazywane społeczeństwu treści pozostawały $\mathrm{w}$ zgodzie $\mathrm{z}$ jej oczekiwaniami, nie narażając jej na sprzeciwy opinii publicznej. To język, jako podstawa komunikacji społecznej, stał się symbolem tożsamości politycznej i okazał się najlepszym, bo elastycznym, tworzywem kształtowania przychylnej państwu opinii. Stąd nic dziwnego, że różne formy dyskursu czasów nowożytnych zaczęły przyciagać uwagę myśli postmodernistycznej. Dlatego studia nad znakiem, językiem,

językiem. Por. i d e m, Czy państwo narodowe ma przyszłość, [w:] i d e m, Uwzględniajac Innego, Warszawa 2009, s. 111-158. Ponadto wykorzystano w artykule następujace prace: A.D. S m it h, Nacjonalizm. Teoria, ideologia, historia, Warszawa 2007; E. G e 11n e r, Narody i nacjonalizm, Warszawa 2009.

3 Faktycznie przedstawiciele postmodernizmu zgodzili się z poglądem E. Burke’a, że abstrakcyjne prawa człowieka, które jakoby maja istnieć niezależnie od jakiejkolwiek wspólnoty, nie sa w istocie żadnymi prawami. Por. id e m, Rozważania o rewolucji we Francji, Kraków-Warszawa 1994. W nurcie postmodernistycznym podobne wnioski formułuje M. M affe s oli, Czas plemion, Warszawa 2008, choć nie powołuje się na osiemnastowiecznego myśliciela. Zadał on sobie często występujące w literaturze pytanie, czy jesteśmy w stanie sprostać wyzwaniom współczesności w czasach ciagłego odwoływania się do formalnego i instytucjonalnego zarządzania społeczeństwem. Dodajmy, że jest to wiodący nurt badawczy postmarksizmu, szczególnie widoczny w: E. L a cla u i Ch. M o u ffe, Hegemony and Socialist Strategy: Towards a Radical Democratic Politics, LondonNew York 1985; E. L a c la u, New Reflection of Our Time, London-New York 1990, s. 17 i n. $Z$ innych wykorzystanych prac: S. Ha11, The problem of ideology. Marxism without guarantees, [w:] D. M o r t e y, K.H. C h e n, S. H a 11, Critical Dialogues in Cultural Studies, London 1996. 
a szerzej tekstem, dialogiem, dyskursem nabrały w niej trwałego i dominujacego charakteru. Oczekiwano od nich nie tylko rozpoznania właściwych znaczeń występujących w tekstach, ale wykazania, iż każdy $z$ nich jest jedynie indywidualna interpretacja, której nie należy nadawać charakteru ostatecznego zapisu o arbitralnym wydźwięku. W odczuciu myślicieli postmodernistycznych czyniono to wielokrotnie $z$ wybranymi tekstami przez nadawanie im znaczeń powszechnych i obowiązujacych zarazem, marginalizujacych zastrzeżenia mniejszości. Dlatego rozważaniom nad „natura” dyskursu $z$ czasem przypisano walor zabiegu metodologicznego umożliwiajacego nie tyle krytyczne, ile wielopłaszczyznowe odczytywanie tekstu, osłabiajace jego autorytarne zapędy ${ }^{4}$.

Modne obecnie pojęcie dyskursu w naukach humanistycznych, obrastajace stale nowymi kontekstami, trudno uznać za w pełni domknięte. Dla jednych analiza dyskursu sprowadza się do pojedynczej wypowiedzi lub co najwyżej do dialogu dwojga osób przypominającego żywo sokratesowskie polemiki zapisane w dialogach Platona. Dla innych dyskurs jest synonimem systemu społecznego konstytuującego dostępny nam świat społeczny i polityczny. Przykładowo dla E. Laclau i Ch. Mouffe zajmujacych się dekonstrukcyjna interpretacja marksizmu, pojęcie „dyskursu” wpisuje się w przekonanie, że tzw. praktyka artykulacji, czyli sztuki wiąania punktów węzłowych, odpowiedzialnych za wytworzenie i stabilizowanie znaczeń językowych, oznacza w praktyce, że „każdy dyskurs ustanowiony jest jako wyłącznie próba opanowania dyskursywności, zahamowania swobodnego przepływu różnic, stworzenie pewnego centrum" 5 . W ich rozumieniu dyskurs nie ogranicza się do zjawisk

4 Przykładem radykalnej odmiany koncepcji „języka” sa prace M. Pecheux, który w nawiązaniu do teoretycznych koncepcji L. Althussera i J. Lacana zakłada, że znaczenie jest wynikiem interpretacji, czyli takiej sytuacji, w której wytwarzanie znaczeń zachodzi wraz $z$ przemiana jednostki w podmiot dysponujacy określonym doświadczeniem i rozumieniem świata. Zjawisko tej przemiany wyjaśnia mechanizm artykulacji, w której podmiot stara się uporządkować znaczenie w ramach prowadzonego dyskursu, umożliwiającego mu wypracowanie spójnej całości. Wtedy dopiero narracja nabiera cech wypowiedzi naturalnej, spójnej i normalnej. Więcej na ten temat por. i d e m, Language, Semiotics and Ideology, London 1982, s. 188 i n. Warto podkreślić, iż w nurcie postmarksistowskim postmodernizmu, w pracach Th. Adorno, H. Arendt, J. Habermasa, E. Laclau i A. Touraine'a przewija się stwierdzenie, że każdy typ państwa totalitarnego jest $\mathrm{w}$ istocie oparty na propagandzie, pozostając w zupełności obojętny na tzw. matematykę rzeczywistości.

5 Termin artykulacji jako istotny dla filozofii, teorii języka i polityki bywa też zastępowany pojęciem wiązania występującym w pracach na temat teorii dyskur- 
czysto językowych, lecz obejmuje także wszelkie praktyki i stosunki społeczne. Tym samym, nie jest jedynie „bytem” poznawczym czy kontemplacyjnym, ale konstytuującym, określającym i opisującym relacje społeczne. Jeszcze innego znaczenia nabiera dyskurs w rozważaniach J. Derridy, nadającego mu walor ujęcia narracyjnego i zarazem kreatywnego, który nie uzyska miana statusu jeśli temu, "co ukryte, nie zostaje zagwarantowane przez system konwencji zapewniających mu jednocześnie wpisanie na wspólna historię przynależności do pewnej kultury, dziedzictwa, społecznej tradycji, pedagogicznej dyscypliny i łańcucha pokoleń”. W nim „odkrycie, czyli inwencja zostaje zastosowana tylko po to, by odkrycie mogło być podważone, wykorzystane i wpisane w odmienne konteksty". Przekładajac to na język bliższy historykowi, dyskurs jawi się jako nigdy nie domknięta narracja podatna na każda indywidualną interpretację. Dla ojca dekonstrukcji, a chodzi tutaj konkretnie o rozważania nad tekstem, jest to nieprzerwany łańcuch interpretacji odsłaniających różne jego znaczenia w serii wzajemnych, powiązanych twierdzeń. Filozof, który zakwestionował zdolność języka do zapewnienia podmiotowi bezpośredniego dostępu do świata przedmiotów, podkreśla tym samym, że idee, słowa i rzeczy nie moga być nigdy wiernie oddane przez język. Akcentował nie tyle niemożność ich doprecyzowania przez słowa-znaki, ile to, że moga one być powtarzane nieskończenie wiele razy w różnych kontekstach znaczeniowych. I w tym sensie znaki sa bytami, które maja charakter historyczny i kontekstowy. Nie można raz na zawsze ustalić tożsamości znaku, a tym samym ustabilizować relacji między tymi bytami. Niemożność umiejscowienia, jak i zachowania bez zmian wszystkiego, co jest oryginalne, w przeciwstawieniu do tego, co można określić jako uzupełnienie, skazuje wszelkie próby poszukiwania ich istoty na porażkę. Relacja między źródłem, określanym w tekstach postmodernistycznych jako "esencja” czy „wnętrze”, a uzupełnieniem rozumianym jako przygodność, zewnętrzność, przybiera w ujęciu J. Derridy charakter nierozstrzygalności, przynoszący rewolucyjne rozwiazania $\mathrm{w}$ kwestii pracy nad tekstem. Dowodzi bowiem, że wszystkie badania nad tekstem w dyskusji między nim a badaczem sa $z$ zasady wielopłaszczyznowe i nierozstrzygalne ${ }^{6}$.

su u E. Laclau i Ch. Mouffe. Por. e o r u n d e m, Hegemonia i socjalistyczna strategia. Przyczynek do projektu radykalnej polityki demokratycznej, Wrocław 2007.

6 J. De rrida, Psyche. Odkrywanie innego, [w:] Postmodernizm. Antologia przekładu, red. R. Nycz, Kraków 1998, s. 81-108; i d e m, O gramatologii, przekł. 
$Z$ pewnością nie zgodziłbym się $z$ tymi wywodami $H$. Arendt, która rozdziałowi pierwszemu pracy $O$ rewolucji nadała znamienny tytuł Czym jest rewolucja?, śledząc w nim zmieniające się historycznie znaczenia tego słowa i towarzyszace mu konteksty na przestrzeni kilku wieków doby nowożytnej7. Podobnie postępuje R. Koselleck, który w opracowanym słowniku pojęć podstawowych typu „rewolucja”, „oświecenie”, „porzadek społeczny”, „kryzys”, dochodzi do wniosku, że przy zrozumieniu ich znaczenia nie można poprzestać jedynie na ich bieżacym, chwilowym zastosowaniu. Konieczne jest wejrzenie we wszystkie poziomy jego użycia, począwszy od aktorów zdarzeń a skończywszy na interpretacjach prezentowanych przez kolejne pokolenia historyków ${ }^{8}$.

Trudno też przy wstępnych rozważaniach o naturze dyskursów pominąc osobę M. Foucaulta, który wypracował sobie niezależna pozycję w postmodernizmie. Nie tylko przedstawił znaczacy i niejednoznaczny zbiór wskazówek metodologicznych odnoszacych się do praktycznej analizy dyskursu, ale także zaproponował szereg wniosków dotyczących natury władzy i wiedzy ${ }^{9}$. Umieścił je w klu-

B. Banasiak, Warszawa 1999; idem, Marginesy filozofii, przekł. A. Dziadek, J. Margański, P. Pieniążek, Warszawa 2002, s. 384 i n. Por. też J. H a b e r m a s, Filozoficzny dyskurs nowoczesności, przekł. M. Łukaszewicz, Kraków 2000, s. 205211; D. H ow a r d, Dyskurs, Warszawa 2008, s. 63-80.

7 Można tutaj zwrócić uwagę na efekty zastosowania metody etymologicznej jako koniecznej do ustalenia dokładnego znaczenia podstawowych pojęć w pracach H. Arendt, zwłaszcza wątku natężenia i konieczności oraz stosunku wyjątku do normy. Por. e a d e m, O rewolucji, Kraków 1991, rozdz. I. Godne podkreślenia jest to, że H. Arendt była jednym $z$ pierwszych badaczy, który przez erę nowożytności rozumiał epokę zaczynająca się od wielkich odkryć geograficznych i naukowych, czasów Kolumba i Kopernika, i zamykał ją na wieku dwudziestym wraz z pierwszymi wybuchami atomowymi. Wywarła więc wpływ na periodyzacje obowiązująca $w$ antropologii historycznej, z podziałem na przednowoczesność, nowoczesność i ponowoczesność, raczej obca tradycyjnej historiografii. Por. e a d e m, The Human Condition, Chicago 1985, s. 6.

8 Więcej: D.R. Kelley, Granice historii. Badanie przeszłości w XX wieku, Kraków 2009, s. 199-200.

9 Odwołuję się do następujacych prac: M. Foucault, Archeologia nauk humanistycznych, przekł. T. Komendant, Gdańsk 2006, s. 118 i n.; i d e m, Nadzorować i karać. Narodziny więzienia, przekł. T. Komendant, Warszawa 1993, s. 161; i d e m, Trzeba bronić społeczeństwa. Wykłady $w$ College de France, 1776, przekł. M. Kowalska, Warszawa 1998. Korzystam też z opracowań: P. P a t to n, Foucault, [w:] Myśliciele polityczni od Sokratesa do współczesności, red. D. Boucher i P. Kelly, Kraków 2008, s. 685-710; A. K a p u s t a, Filozofia ekstremalna. Wokół myśli krytycznej Michela Foucaulta, Lublin 2002. 
czowych dla niego pojęciach „biowładzy' i „mocy wiedzy” istotnych dla zrozumienia zmian, jakie nastapiły w nowożytności i w czasach nam współczesnych. Wyróżnił w nich różne, nieraz sprzeczne względem siebie, formy pojmowania dyskursów, raz jako autonomicznego systemu reguł zarządzających procesem wytwarzania twierdzeń naukowych, innym razem pojmował je jako ujęcia o charakterze strategicznym, służące partykularnym interesom i projektom rozumienia ładu społecznego. Takie dyskursy zawierają w sobie, jako to określał, „punkty oporu” umożliwiajacce powstawanie strategii przeciwstawnych w stosunku do strategii dominacji. Widoczne niekonsekwencje i niejasności jego ujęć dyskursu określił $z$ sarkazmem zwolennik poetyki pisarstwa historycznego H. White „dyskursem o dyskursie”. Postrzegane niekonsekwencje M. Foucaulta bywaja tłumaczone jako przykład faz rozwoju myśli francuskiego myśliciela i zdają się potwierdzać, że „dyskurs”, zarówno w formie dialogu, jak i narracji, trzeba uznać za obowiazkowo otwarty ${ }^{10}$.

I choć w twórczości francuskiego myśliciela wyróżnia się dwa okresy badań nad dyskursem, faza studiów nad jego archeologicznym ujmowaniem $z$ lat sześćdziesiatych wieku XX i genealogicznym $z$ następnego dziesięciolecia, to $\mathrm{w}$ niniejszym wystapieniu interesuje nas ta druga formacja, w której badaniom poddano to, co zostało wykluczone $z$ niego wskutek oddziaływania władzy i systemów dominacji. W jego praktyce badawczej oznacza to wydobywanie $z$ nich nowych kontekstów znaczeń, które były świadomie zaciemniane, przeinaczane bądź marginalizowane. Stąd pojęcia dyskursu, tak fundamentalnego dla całego postmodernizmu, trudno nie zaliczyć do terminów złożonych, ciagle podatnych na wpływ bieżących kontekstów i stale reinterpretowanych. Można nawet pokusić się o ujęcie dyskursu postmodernistycznego jako pojęcia amorficznego, w sumie wieloznacznego i dla części historyków praktycznie mało przydatnego. W przeciwieństwie do pozytywistycznych jego ujęć, postmodernistyczne wersje nabieraja cech ontologicznych zarówno w teorii, jak i w praktyce, ponieważ wysiłek nie ma tutaj służyć rozpoznaniu wyobrażeń i sądów powszechnych służących społeczeństwu. Inaczej mówiąc, tekst postmodernistyczny ma charakter czysto poznawczy i z założenia jego narracja ma być

10 Na niedoskonałości Foucaultowskiej koncepcji władzy oraz braku jasności co do jej związków z takimi pojęciami, jak „dominacja”, „opór podmiotu” zwraca uwage D. Howard. Por. id e m, op. cit., s. 132. Dobrym tego przykładem jest cykl wykładów w College de France. Por. M. F o u c a u 1 t, Trzeba..., passim. 
wolna od wszelkich sugestii i nakazów natury politycznej. U podstaw tak rozumianej narracji leży dążenie do przetwarzania i pomnożenia wiedzy o właściwościach języka, który pozostaje kluczem do poznania i zrozumienia świata, umożliwiającym pełniejszy opis rzeczywistych relacji zachodzacych między człowiekiem a otoczeniem. Język jest najważniejszym narzędziem, jakim dysponujemy przy opisach świata i relacjach zachodzacych między ludźmi. Można tutaj odwołać się do Biblii, która mówi, że na początku było słowo i to się przekłada na ten metaforyczny sens zastosowania języka do badań społecznych w różnych odmianach współczesnego nam postmodernizmu. Jednocześnie $\mathrm{w}$ takim mocnym akcentowaniu roli języka widoczne jest przeświadczenie postmodernizmu o jego społecznie wyjatkowej roli informacyjnej i komunikacyjnej ${ }^{11}$.

Sformułowana przez szwajcarskiego językoznawce F. de Saussure'a teoria języka jako formy, a nie substancji, podkreślająca że składa się on $z$ różnic, a nie ze składników pozytywnych, określa pozycje znaku, czyli słowa jako relacji o charakterze arbitralnym między jego elementem znaczonym a znaczacym. Jak to de Saussure lapidarnie ujął w Kursie językoznawstwa ogólnego: „Cały mechanizm języka polega na opozycjach oraz na różnicach dźwiękowych i pojęciowych"12. Takie rozumienie natury języka zostaje wprowadzone do założeń metodologicznych strukturalizmu C. Levi-Straussa i bywa przetworzone w narrację o zasadach funkcjonowania społeczeństwa pierwotnego. Nabywa narracja cech tekstu nie wolnego od subiektywnych odczuć, ponieważ zawsze jest to tekst autorski, wolny od kanonu wiedzy obiektywnej zalecanej przez dyskurs pozytywistyczny i naturalistyczny ${ }^{13}$. Szwajcarski ję-

11 Jest to szczególnie widoczne w pracach L. Althussera, który twierdzi, że nikt nie jest wolny od praktyk ideologicznych, wszyscy jesteśmy w nich zanurzeni i nie mamy szans od nich uciec. Obszerniej na ten temat por. i d e m, Ideologia $i$ aparaty ideologiczne państwa; wskazówki do poszukiwania, przekł. B. Poniakowski, J. Gajda, Warszawa 1983, s. 89 i n.; N. F a ir clough, Language and Power, London 1990; R. B a rthes, Podstawy semiotyki, przekł. A. Turczyn, Kraków 2009.

12 Cyt. za: F. d e S a u s s u r e, Kurs językoznawstwa ogólnego, przekł. K. Kasprzyk, Warszawa 1991, s. 53 i n. Omówienie w pracy: D. H ow a rd, op. cit., s. 36 i n.; J. L e c h t e, Panorama współczesnej myśli humanistycznej. Od strukturalizmu do postmodernizmu, Warszawa 1999, s. 269-278. Por. też R. B a rthe s, op. cit., passim.

13 Stąd wyodrębnienie przez C. Levi-Staussa trzeciego aspektu języka mitu, który obok Saussureowskiego „parole” i „langue” umożliwia analizowanie roli, jaka odgrywa on w ludzkiej zbiorowości. Relacje zachodzace między nimi pozwalaja 
zykoznawca przyznaje, że badacz jest częścią wytworzonych społecznie znaczeń i praktyk, stąd nie może oceniać świata oczyma „neutralnego widza”. Dla P. Wincha, autora pracy Idea nauki $w$ społeczeństwie $i$ jego zwiazki z filozofia sensowne rozpoznanie reguł zachowań społecznych winno sprowadzać się do uchwycenia tego, co się robi lub mówi. W jego przekonaniu, badacz społeczny ma do czynienia $z$ bardziej złożoną sytuacją niż przedstawiciel nauk przyrodniczych, ponieważ zarówno badacz, jak i przedmiot jego badań są konstruktami społecznymi, wytworami praktyk znaczeniowych. Badacz musi być świadom reguł i konwencji rzadzaccych jego profesja na równi ze świadomościa praw rządzących przedmiotem jego badań ${ }^{14}$. Nauki społeczne nie sa w stanie sformułować obowiązującego paradygmatu w rozumieniu Th. Kuhna i dlatego każda narracja ma tutaj wymiar jednostkowy. Nauki społeczne pozostają więc wielkim zbiorem takich indywidualnych podejść do tematu studiów, w czym ujawnia się coraz szerzej rozumiana słabość takich ujęć, prowadząca do anarchizacji osiagnnięć humanistyki15.

Inne podejście proponuje hermeneutyka, czyli jeden $z$ nurtów postmodernizmu. Tutaj celem dyskusji jest jedynie rozumienie $i$ interpretowanie społecznie wytwarzanych znaczeń, a nie ujmowanie tekstu w relacjach przyczynowo-skutkowych, które, nawiasem mówiąc, cechuje dyskurs racjonalistyczny o oświeceniowych korzeniach powszechnych, jak dotą, w narracji historycznej. Zasadniczym celem studiów nad tekstem hermeneutów jest odkrywanie historycznie uwarunkowanych reguł i konwencji, które ponosza odpowiedzialność za powstanie znaczenia. Poszukuje się odpowiedzi na pytanie jak i dlaczego aktorzy społeczni utożsamiają się $z$ określonym systemem znaczeń. Może on być ujmowany jako odzyskiwanie znaczeń początkowo niejasnych lub tylko częściowo przedstawionych. Jest w tym nurcie obecna „hermeneutyka podejrzeń", używając języka P. Ricoeura, poszukująca ukrytych znaczeń takich pojęć, jak „walka klas”, „wola społeczna” czy „nieświadomość”, występujących w pismach K. Marksa, F. Nietzschego i Z. Freuda.

nam dotrzeć do uniwersalnych struktur, które sterują wytwarzaniem i transformacja mitów w społeczeństwie. Por. i d e m, Antropologia strukturalna, przekł. K. Pomian, Warszawa 2009.

${ }_{14} \mathrm{P}$. W in ch, Idea nauki o społeczeństwie i jej zwiazki z filozofia, przekł. B. Chwedeńczuk, Warszawa 1995, s. 32.

15 Th. K u h n, Struktura rewolucji naukowych, przekł. H. Ostromęcka, Warszawa 2001. 
Jej celem jest demaskowanie powierzchownych znaczeń i towarzyszacych im bałamutnych komentarzy ${ }^{16}$. Takie rozpracowywanie tekstu było szczególnie bliskie M. Foucaultowi, który starał się rozpoznać ich znaczenie w wyniku wzajemnych relacji władzy i wiedzy. W Nadzorować i karać stwierdził: „władza i wiedza wprost się ze soba wiąża, że nie ma relacji władzy bez skorygowania $z$ nim pola wiedzy, ani też wiedzy, która nie zakłada i nie tworzy relacji władzy"17. Wsparł to przykładem zachowań nowożytnych państw europejskich, w których zachodziły organiczne związki między dyskursem nauk o człowieku a akcentowanymi technikami dyscyplinującymi i zniewalającymi jego ciało i duszę. Francuski myśliciel nie ustawał $\mathrm{w}$ wysiłkach dopracowania się takiej nieredukcyjnej koncepcji dyskursu, która uniknęłaby arbitralnych wniosków. Podkreśla, nie bez słuszności, że w dyskursie prowadzonym pomiędzy władzą a wiedza trudno go rozdzielać na akcentowany i odrzucony, albo inaczej mówiąc, dominujący i zdominowany. Trzeba raczej przyjąć występowanie wielości dyskursywnych elementów zawartych w rozmaitych strategiach. Pisał, że „zbiegaja i rozchodzą się w nich treści wyrażone i zatajone, narzucone i zalecane, zróżnicowane od strony osób w nich uczestniczacych, ich usytuowania w społeczeństwie i dążeń, do których zmierzają, konkludując „dyskursy nie sa raz na zawsze poddane władzy lub przeciwko niej obrócone. Założyć trzeba istnienie złożonej i niestabilnej gry, w której dyskurs stanowić może instrument i środek władzy, lecz także przeszkodę, zawadę, punkt oporu i zapowiedź opozycyjnej strategii. Dyskurs przerywa i produkuje władzę, zmiękcza i sprzyja jej tamowaniu"18. W tej gęstej tkance dyskursów głosy instytucji, zbiory norm prawnych, projekty reform administracyjnych, głosy osób publicznych i prywatnych, osady moralne, rozważania filozoficzne, programy stowarzyszeń gospodarczych i filantropijnych mieściły się w mechanizmie znaczeń, które badacz konceptualizuje w ramach relacji władzy i wiedzy. Wpisanie ich w tekst pozwala ogarnać świat różnych, wzajemnie wykluczających się znaczeń i zachowań ludzkich. Wyraża się $\mathrm{w}$ tym naczelna tendencja postmodernizmu do dystansowania się od wszelkich form opowieści w kształcie po-

$16 \mathrm{P}$. R i c o e u r, The model of the text: meaningful action considered as a text, „Social Research” 1971, No 38 (3), s. 529-562; i d e m, Czas i opowieść. Intryga $i$ historyczna opowieść, t. I, cz. 2 (Historia i powieść), Kraków 2008.

17 Cyt. za: M. F o u c a u 1 t, Nadzorować i karać..., s. 38.

18 Ibidem, s. 90 i n. 
uczeń i nakazów, zwłaszcza natrętnie występujących w programach ideologicznych, trywializujących czy wręcz wulgaryzujących opisywana rzeczywistość. M. Foucault pozostaje przeciwny stosowaniu pojęcia ideologii do tekstów humanistycznych podkreślając, że ustawiaja się one w opozycji do czegoś co ma uchodzić za prawdę. W Słowach $i$ rzeczach utrzymuje, że nie tyle ważne jest odróżnienie wypowiedzi prawdziwych od fałszywych, ile przeprowadzenie analizy historycznych warunków wytwarzania efektów prawdy, jak to nazywa. Stąd jawi mu się ideologia jako zabieg ułatwiajacy manipulowanie podmiotem, który w tym stanie rzeczy nie może osiągnąć stanu oświecenia ${ }^{19}$. Nadał więc ideologii charakter czynnika dyscyplinującego społeczeństwo, będącego w rzeczywistości zabiegiem homogenizujacym, zacierającym tak oczywiste między ludźmi różnice.

W ostatnich trzydziestu latach ubiegłego stulecia sporom o funkcje i charakter narracji w naukach spolecznych towarzyszyło pytanie o wartość w nich tzw. zwrotu lingwistycznego ${ }^{20}$. Nie było to zwyczajne upomnienie się o literackość tekstów humanistycznych, ale także rewanż literatury za lata dominacji w nich surowego, hermetycznego zapisu języka naukowego. W rzeczywistości zwrot lingwistyczny zrodził szereg pytan dotyczacych zabiegów heurystycznych, zalecających badaczom odwołanie się do subiektywnych źródeł natrętnie postulowane przez krytyków literackich. Oznacza to skierowanie uwagi badacza w stronę sztuki, w której jest miejsce na emocje i wyobraźnie. Jest to postulat, który H. White ładnie określił jako poetykę pisarstwa historycznego ${ }^{21}$. Nie jest to oczywiście żadna rewolucja w narracji historycznej, czego przykładem może być pisarstwo J. Burcharda. We wstępie do najbardziej znanej $\mathrm{z}$ jego prac Kultura Odrodzenia we Włoszech czytamy: „Kontury duchowe pewnej epoki kultury przedstawiaja może dla każdego oka obraz odmienny”, dodając zarazem „najistotniejsza trudność historii kultury polega na tym, że wielka ciagłość duchowa musi rozkładać się na poszczególne, nieraz pozornie dowolne

19 M. F a u c a u 1 t, Słowa i rzeczy. Archeologia nauk humanistycznych, przekł. T. Komendant, Gdańsk 2006, s. 116; i d e m, Czym jest oświecenie, [w:] Filozofia, historia, polityka. Wybór pism, przekł. D. Leszczyńska, L. Rusiński, Warszawa-Wrocław 2000, s. 286.

20 Więcej na ten temat por. J. A p pleby, L. Hun t, M. J a cob, Powiedzieć prawdę o historii, Poznań 2000; D.R. K e11y, op. cit., s. 251 i n.

${ }^{21} \mathrm{H}$. W h i t e, Poetyka pisarstwa historycznego, red. E. Domańska i M. Wilczyński, Kraków 2000, s. 267 i n. 
kategorie, by się w jakikolwiek sposób przedstawić"22. Innymi słowy, kontury każdej narracji inaczej sa zarysowane, stąd pisarstwo historyczne jest kwestią wyobraźni, bez której trudno zrekonstruować obraz przeszłości. Rekonstrukcje takiego sposobu ujmowania historii znajdujemy u innego bazylejskiego profesora F. Nietzschego, który wyciagnał skrajne konsekwencje $z$ burckhardowskiego obrazu włoskiego renesansu. Do jego poglądów nawiąał i przetworzył je na swój sposób M. Heidegger, zwracając uwagę na specyficzny, dialogiczny charakter prac historycznych, nie pozostajacy bez wpływu na ujęcie interpretacje tekstu przez historyka. Dokonane przez niego rozróżnienie na dokumentalny i i wypracowany aspekt tekstu oznacza wyodrębnienie dwóch różnych sposobów przedstawień historiograficznych: naukowo-faktograficznego L. von Rankego i estetyzującego ujęcia J. Burckharda. Wskazuja one na odmienne, rozumowe i emocjonalne podejście badacza do tekstu. I choć w praktyce przełamuje się je w narracji historycznej przez wiazanie wyobraźni, zdrowego rozsadku i doświadczenia, to w odczuciu filozofów języka i badaczy literatury nie sa to zabiegi zadowalajacce. $Z$ drugiej strony, to poszukiwanie niezamierzonych i niezauważonych znaczeń prowadzi do lekceważenia wartości poszukiwań archiwalnych, w których przecież mieści się całe niewyobrażalne bogactwo form i treści przeszłości, dlatego nie ma potrzeby podejmowania w tej materii odrębnych teoretycznych studiów ${ }^{23}$.

Widoczny w ruchu postmodernistycznym zwrot w stronę historii kultury nie pozostaje bez wpływu na to, że postrzega się tekst jako obraz, rodzaj metaforycznej przypowieści o moralnym wydźwięku, odrzucający realizm L. Rankego i kwestionujący walor nadania ostatecznego znaczenia opisywanym wydarzeniom. Ten sposób prezentowania tekstu mieści się w definicji „przygodności”, pojęciu kluczowym dla nurtu postmodernistycznego drugiej połowy ubiegłego stulecia. Odwołamy się tutaj do definicji przygodności, pióra amerykańskiego filozofa R. Rorty'ego, piszącego: „Opowieść, która snują historycy [...] można $z$ grubsza podsumować, powiadając, że kiedyś dawno, dawno temu, odczuwaliśmy potrzebę

22 J. B u rkh ard, Kultura Odrodzenia we Włoszech, Warszawa 1961, s. 5; D.R. Ke $11 \mathrm{y}$, op. cit., s. 179 i n.

23 Więcej por. H. W h it e, Fikcja historyczna, historia fikcjonalna i rzeczywistość historyczna, [w:] Proza historyczna, red. E. Domańska, Kraków 2009, s. 183198; F. A n k e r s m i t, Narracja, reprezentacja, doświadczenie. Studia z teorii historiografii, Kraków 2004. 
czczenia czegoś, co spoczywa poza granicami świata widzialnego. Począwszy od wieku siedemnastego miłość do Boga staraliśmy się zastapić umiłowaniem prawdy, traktujac przy tym opisywany przez naukę świat jako quasi-bóstwo. Począuszy od końca osiemnastego wieku w miejsce miłości do prawdy usiłowaliśmy postawić umiłowanie siebie samych, cześć dla naszej własnej, głęboko duchowej bądź poetycznej natury, uznanej za quasi-bóstwo". I nieco dalej: „człowiek, anulując je, czyni, że nasz język, nasze sumienie, nasza wspólnotę - traktować będziemy jako wytwór czasu i przypadek, a mówiąc słowami $Z$. Freuda uznamy przypadek za godny decydowania o naszym losie"24.

Według postmodernistów narracja doby nowożytnej została zdominowana przez hegemoniczne punkty widzenia. Zdaniem M. Allena współczesnym obowiązkiem badacza jest „uniknąć zhomogenizowania i nie poddać się zsyntetyzowanej różnorodności. Nie ma bowiem żadnej prostej recepty, która zapewniłaby skuteczne dotarcie do prawdy”. Stąd postmoderniści akcentują wartość „ironii”, czyli zachowania takiej postawy, która umożliwia nam utrzymanie dystansu w akcie pisania pomiędzy teraźniejszością a przyszłością, pomiędzy czasem utraconym a poszukiwanym, jak ujął to M. Proust. I chociaż niemożliwy jest w narracji „widok bez punktu widzenia", czy uprawianie historii bez historyka, co zdaje się przewrotnie sugerować znaczna część postmodernistów, to widoczna jest w nim tendencja do usunięcia $z$ narracji „determinizmów”, tak żywotnych $\mathrm{w}$ myśli oświecenia. Stąd wyrasta postulat poszukiwania takich wzorców opowieści, które nie zawierałyby „izmów” i uwolniłyby ludzkość od konieczności działań opartych na dominacji, nakazie i nietolerancji. Jest $\mathrm{w}$ tym zawarta ukryta myśl nieantagonizowania ludzkich wspólnot, co było tak nadużywane przez państwa narodowe w nowożytności. Sugeruje się, że bogactwo jednostkowych postaw i zachowań, czasem charakteryzowane jako "odmienność” czy „inność” jest naturalnym, choć słabo postrzeganym walorem ludzkiego gatunku. Jednostka funkcjonujacca we wspólnocie ma tendencję do stałego zaznaczania swojej odrębności tak w zachowaniach, jak i w czynach, nie mówiąc już o myślach. Tym samym takie postawy pozostawały sprzeczne $z$ tendencjami państwa nowożytnego, zwłaszcza w jego narodowym wydaniu, preferującego jedność społeczna jako jeden $z$ wyróżników siły i potęgi. W tym ujęciu

${ }^{24}$ Cyt. za: R. Ro rty, Przygodność, ironia i solidarność, przekł. W.J. Popowski, Warszawa 2009, s. 48. 
każda jednostkowa odrębność była zagrożeniem dla interesów państwa. A przecież różnorodność może być źródłem siły, a nie słabości ludzkiego gatunku. Choć może nie jest to możliwe do urzeczywistnienia, zważywszy na historyczne zaszłości, jakimi obrosły poszczególne nacje, bo - jak mawiaja przyrodnicy - teorie mijaja, żaba zostaje. 